\title{
Cell Cycle Arrest by Supraoptimal Temperature in the Alga Chlamydomonas reinhardtii
}

\author{
Vilém Zachleder ${ }^{1, \dagger}$, Ivan Ivanov ${ }^{1,2, \dagger}$, Milada Vítová $^{1}$ (1) and Kateřina Bišová ${ }^{1, *}$ (i) \\ 1 Laboratory of Cell Cycles of Algae, Centre Algatech, Institute of Microbiology of the Czech Academy of \\ Sciences, 37981 Třeboň, Czech Republic; zachleder@alga.cz (V.Z.); ivanov@alga.cz (I.I.); vitova@alga.cz (M.V.) \\ 2 Faculty of Science, University of South Bohemia, Branišovská 1700, 37005 České Budějovice, Czech Republic \\ * Correspondence: bisova@alga.cz; Tel.: +420-384-340-485 \\ + These authors contributed equally to this work.
}

Received: 26 August 2019; Accepted: 8 October 2019; Published: 11 October 2019

\begin{abstract}
Temperature is one of the key factors affecting growth and division of algal cells. High temperature inhibits the cell cycle in Chlamydomonas reinhardtii. At $39^{\circ} \mathrm{C}$, nuclear and cellular divisions in synchronized cultures were blocked completely, while DNA replication was partly affected. In contrast, growth (cell volume, dry matter, total protein, and RNA) remained unaffected, and starch accumulated at very high levels. The cell cycle arrest could be removed by transfer to $30^{\circ} \mathrm{C}$, but a full recovery occurred only in cultures cultivated up to $14 \mathrm{~h}$ at $39^{\circ} \mathrm{C}$. Thereafter, individual cell cycle processes began to be affected in sequence; daughter cell release, cell division, and DNA replication. Cell cycle arrest was accompanied by high mitotic cyclin-dependent kinase activity that decreased after completion of nuclear and cellular division following transfer to $30^{\circ} \mathrm{C}$. Cell cycle arrest was, therefore, not caused by a lack of cyclin-dependent kinase activity but rather a blockage in downstream processes.
\end{abstract}

Keywords: cell cycle arrest; cell size; Chlamydomonas reinhardtii; cyclin-dependent kinase; DNA replication; synchronized cultures; supraoptimal temperature; starch accumulation

\section{Introduction}

Light and temperature are two key factors that affect growth and development of plants, including green algae. For each organism, there are three temperature ranges with distinct effects on cell physiology. Firstly, the optimum growth temperature is where growth rate reaches a maximum. Secondly, the range below and above the optimum is where growth and cell division are possible, yet at lower rates. The final range is temperatures too low or too high to allow for cell division, cell growth, or cell survival. Within the physiological range surrounding the optimum, a $10^{\circ} \mathrm{C}$ increase in temperature will increase metabolic rate two-fold. Increasing temperature will thus speed up growth as well as shorten individual phases of the cell cycle and its total duration, as shown in different algae such as Chlorella ellipsoidea [1], Chlamydomonas reinhardtii [2], Chlamydomonas eugametos [3], and Desmodesmus quadricauda [4]. Individual metabolic processes are differentially sensitive to temperature, which contributes to distinct cell responses within a temperature range. Cell division and duration of the cell cycle seem to be more sensitive to temperature than growth. Cultures of $C$. reinhardtii grown at increasing temperatures will, at first, increase growth rates and shorten the cell cycle, as predicted by the two-fold increase in metabolic rate [2]. With a further temperature increase between 28 and $37^{\circ} \mathrm{C}$, duration of the cell cycle will be prolonged, while the growth rates will remain comparable. Since a temperature increase of $10{ }^{\circ} \mathrm{C}$ should double the growth rate, maintaining similar growth rates between the two temperatures implies that the growth rate effectively decreases in contrast to predictions. Thus, although the cells are not yet visibly stressed, such temperatures are physiologically 
supraoptimal. Would a further increase in temperature lead to cell division arrest? When optimizing growth conditions for synchronized cultures of C. reinhardtii, Lien and Knutsen noted that at $1{ }^{\circ} \mathrm{C}$ above the optimal growth temperature, some cells started to exhibit inhibited cell division [5]. But such effects might be so subtle that they can only be detected in synchronized cultures when the entire culture is of a similar age. In distantly related alga, Chlorella vulgaris, an increase in temperature of 6-7 ${ }^{\circ} \mathrm{C}$ above the growth optima arrested nuclear and cellular divisions, but not DNA replication, and the effect on growth was negligible [6]. Cell cycle arrest thus seems to be one of the first physiological processes affected by even small increases in temperature above the optimum, but the nature of the arrest remains unknown. It is unclear if the arrest is caused by an effect on cell cycle regulatory protein activities (such as cyclin-dependent kinases) or by an effect on downstream cell cycle events.

C. reinhardtii is a model species that divides by multiple fission. Its cell cycle can be modeled as a series of overlapping reproductive sequences, each of them consisting of cell cycle entry at commitment point (CP) that switches on DNA replication (S phase), nuclear division (M phase), and cell division (C) (Figure 1) [5,7-10]. During growth in G1 phase, cells attain their first CP, which would lead to completion of a single reproductive sequence (i.e., division into two daughter cells). At sufficiently fast growth rates, they may also attain consecutive CPs $(n)$, each of which will eventually lead to completion of one reproductive sequence [11,12], independent of further energy supply (i.e., even in the dark). The mother cell can, therefore, divide into $2,4,8$, or $16\left(2^{n}\right)$ cells [5].

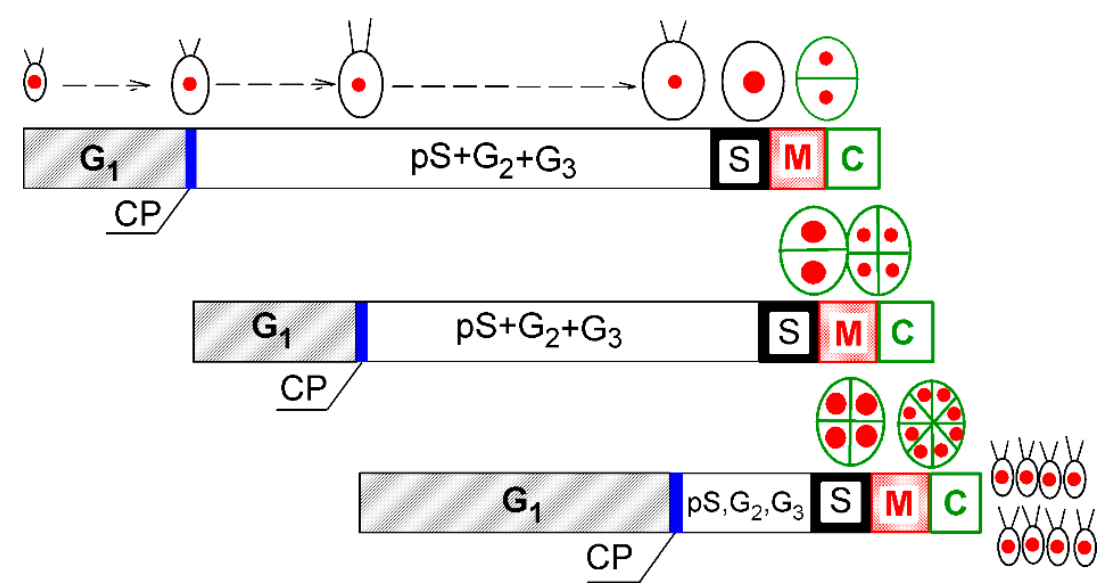

Figure 1. Schematic diagram of growth and the cell cycle in a single cell of Chlamydomonas reinhardtii. The schematic pictures reflect increasing cell size. The red full circles inside the cells illustrate the size and number of nuclei. Larger red circles indicate a doubling of DNA. Green ellipsoids and lines represent protoplast division. Diagram shows a model of cell cycle progression in C. reinhardtii dividing by multiple fission into 8 daughter cells. Three bars indicate three overlapping growth and reproductive sequences terminated by division into 2,4 , and 8 daughter cells, respectively. Precommitment period (G1): the period until threshold critical cell size for commitment to divide (CP) is reached and CP is attained. Postcommitment period consists of $\mathrm{pS}$ - the prereplication phase between the CP attainment and the beginning of DNA replication. The processes required for initiation of DNA replication are assumed to happen during this phase. S: DNA replication takes place. G2: the phase between the termination of DNA replication and the start of mitosis (M). Processes leading to the initiation of mitosis are assumed to take place during this phase. G3: the phase separating mitosis from cellular division, which is clearly visible in some algae dividing by multiple fission. The processes leading to cellular division are assumed to take place during this phase. $C$ : the phase during which cell cleavage (protoplast fission) and daughter cell formation occurs. For C. reinhardtii, it is typical that all "gap" phases are combined into one prolonged phase. The distances between individual cell cycle phases correspond to the cell cycle progression in a real culture (Figure 2). Modified after Zachleder et al. [13], Bišová and Zachleder [14], and Zachleder et al. [15]. 


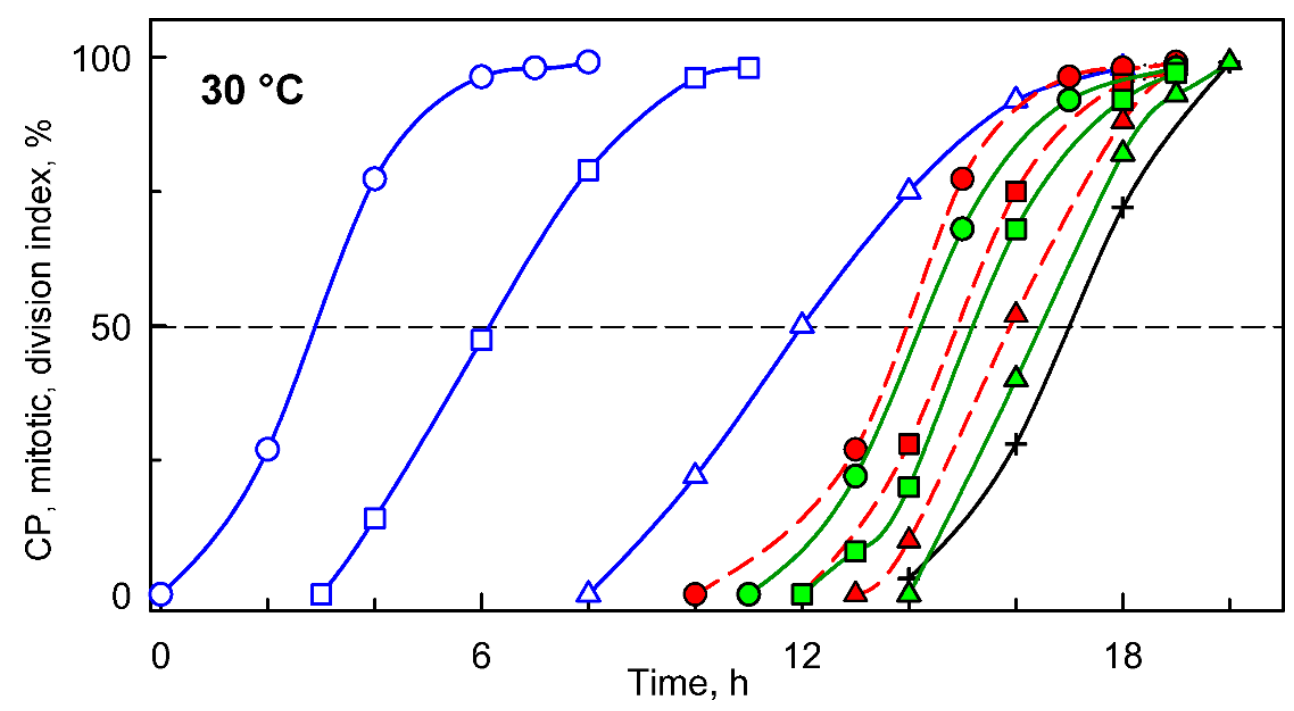

Figure 2. Graphical representation of the cell cycle progression in synchronized cultures of the Chlamydomonas reinhardtii grown at $30{ }^{\circ} \mathrm{C}$ at an incident light intensity of $500 \mu \mathrm{mol} \mathrm{m} \mathrm{m}^{-2}$. Time courses of individual commitment point/s, nuclear division/s, protoplast fission/s, and daughter cell release in synchronized cultures of $C$. reinhardtii. Blue curves (CP indices): cumulative percentage of cells, in a given population (100\%), that attained the commitment point (CP) for the first (circles), second (squares), and third (triangles) reproductive sequence. Red curves (mitotic indices): cumulative percentage of cells, in a given population (100\%), that divided their nuclei into 2 (circles), 4 (squares), and 8 (triangles). Green curves (division/protoplast fission indices): cumulative percentage of cells, in a given population (100\%), that divided their protoplasts into 2 (circles), 4 (squares), and 8 (triangles). Black curve, crosses: cumulative percentage of cells that released daughter cells. Black dashed line at $50 \%$ depicts midpoint of each event in a population of cells.

In single algal cells (and in synchronized cultures that mimic them), growth is manifested by an increase in cell size, RNA, protein, and starch (and other energy components) per cell, which leads to the accumulation of dry matter and an increase in absorbance $\left(\mathrm{A}_{750}\right)$ of the culture. Growth is a prerequisite for cell division, as the attainment of each CP depends on reaching a critical cell size $[10,16]$, which involves a doubling of cell size, cell mass, RNA, and protein per cell $[2,11,12,15,17]$. Growth is, therefore, tightly connected with the cell cycle so the number of reproductive sequences and released daughter cells are dictated by cell size $[10,16]$. Moreover, although there might be growth in the absence of cell division, division in the absence of growth leads to decreasing cell size and is, thus, limited to specific cases. Temperature affects growth as well as the entire cellular metabolism. Thus, it affects the duration of the growth phase prior to attainment of $\mathrm{CP}$, the precommitment period, as well as the postcommitment period, where, under most conditions, growth runs concurrently with reproductive sequences [2-4]. This is in contrast to light that only affects growth and the duration of the precommitment period, but the postcommitment period remains constant $[3,17]$. Thus, the effect of temperature on the cell cycle is quite complex, even within the physiological range.

In plants, including algae, the cell cycle is regulated by two types of cyclin-dependent kinases (CDKs), CDKA and plant-specific CDKB. C. reinhardtii CDKA [18] and CDKB homologues are encoded by single genes [19] and have nonoverlapping functions [20]. CDKA promotes entry into cell division at $\mathrm{CP}$ and is also required to initiate the first DNA replication [20]. CDKB is the specific mitotic kinase that is required for spindle formation, nuclear division, and subsequent rounds of $S$ phase, but not for cytokinesis [20]. Only CDKB is essential, whilst the null mutant of CDKA prolongs growth and delays cell division [21].

In the present paper, we describe the effect of supraoptimal temperature on cell cycle arrest and recovery in synchronized cultures of $C$. reinhardtii. We show that a supraoptimal temperature inhibited cell reproduction and the expenditure of starch, while normal growth continued, leading to 
the formation of giant cells with elevated levels of starch. Cell cycle arrest comprised a block in nuclear and cellular division, while DNA replication was less affected. Arrest was accompanied by high mitotic kinase activities that declined following nuclear and cellular division/s. Cell cycle arrest was, therefore, not caused by a lack of cyclin-dependent kinase activity but rather a blockage in downstream processes.

\section{Materials and Methods}

\subsection{Organism and Culture}

The unicellular alga Chlamydomonas reinhardtii wild-type 21gr (CC-1690) was obtained from the Chlamydomonas Resource Center at the University of Minnesota (St. Paul, MN, USA). The cultures were grown on high salt medium (HS) as described by Sueoka [22] with a doubled concentration of $\mathrm{Ca}^{2+}$ ions and a tenfold increase in $\mathrm{Mg}^{2+}$ ions. Trace elements $(1 \mathrm{~mL}$ per $1 \mathrm{~L}$ of medium $)$ as described by Zachleder and Šetlík [23] were used instead of Hutner's trace elements. For routine subculturing, the cultures were streaked every three weeks onto modified high salt medium solidified by agar and grown at an incident light intensity of $100 \mu \mathrm{mol} \mathrm{m}^{-2} \mathrm{~s}^{-1}$ of photosynthetically active radiation.

\subsection{Synchronization Procedure}

For synchronization, $300 \mathrm{~mL}$ of liquid HS medium was inoculated directly from plates, and the cultures were placed in glass cylinders (inner diameter $30 \mathrm{~mm}$, height $500 \mathrm{~mm}$ ) at $30^{\circ} \mathrm{C}$ and "aerated" with a mixture of air and $\mathrm{CO}_{2}(2 \%, \mathrm{v} / \mathrm{v})$ at a flow rate of $15 \mathrm{~L} \mathrm{~h}^{-1}$. The cylinders were illuminated from one side by a panel of dimmable fluorescent lamps (OSRAM DULUX L55W/950 Daylight, Milano, Italy) with light intensity adjusted to an incident light intensity of $500 \mu \mathrm{mol} \mathrm{m}^{-2} \mathrm{~s}^{-1}$ of photosynthetically active radiation at the surface of the cylinders. Synchronization was carried out by $13 / 11 \mathrm{~h}$ alternating light/dark (L/D) periods, as was described previously [24].

Suspensions of synchronous cells were diluted to a maximum concentration between $1.5 \times 10^{6}$ and $2 \times 10^{6}$ cells mL $\mathrm{mL}^{-1}$ and cultivated in rectangular plate-parallel vessels $(440 \times 245 \times 23 \mathrm{~mm}$, volume $2200 \mathrm{~mL}$ ) at the same incident light conditions as used for synchronization. The flow rate of the aeration mix was $60 \mathrm{~L} \mathrm{~h}^{-1}$. Culture vessels were immersed in water baths kept at constant temperatures of either 30 or $39^{\circ} \mathrm{C}$. Each experiment was carried out in triplicate. Individual processes of the cell cycle were performed at the same time with midpoints varying by a maximum of one hour. Assessments of $\mathrm{CP}$ attainment, cell division, cell size, and cell number were carried out as described by Hlavová et al. [24]. Dry matter was determined according to Brányiková et al. [25].

\subsection{Determination of Total DNA, RNA, Protein, and Starch}

Total nucleic acid was extracted and analyzed according to Wanka [26], as modified by Lukavský et al. [27]. For DNA content, the light-activated reaction of diphenylamine with hydrolyzed DNA was used, as described by Decallonne and Weyns [28] with modifications of Zachleder [29]. The sediment remaining after nucleic acid extraction was used for protein determination after Lowry et al. [30]. Starch content was determined by the anthrone method [31] as modified by Brányiková et al. [25]. Two technical replicates were used for each analysis. Variations between duplicates did not exceed $5 \%$ of the mean.

\subsection{Activity of Cyclin-Dependent Kinases}

Protein lysates were prepared as described by Hlavová et al. [32]. They were directly assayed or affinity-purified by CrCKS1 beads as described by Bisova et al. [19] with modifications as described by Hlavová et al. [32]. Histone H1 kinase activity was assayed as previously described [33] in a final volume of $10 \mu \mathrm{L}$ with either $7 \mu \mathrm{L}$ of clear whole cell lysate or the CrCKS1 beads fraction corresponding to $20 \mu \mathrm{L}$ of whole cell lysate. The reactions were initiated by adding the master mix to a final composition of 20 mM HEPES, pH 7.5, 15 mM MgCl 2,5 mM EGTA, 1 mM DTT, $0.1 \mathrm{mM} \mathrm{ATP,} 0.2 \%(w / v)$ histone 
(Sigma H5505) and 0.370 MBq $\left[\gamma^{32} \mathrm{P}\right]$ ATP. All the chemicals were purchased from Sigma-Aldrich (Prague, Czech Republic).

Proteins were separated on 15\% SDS-PAGE gels [34]. Phosphorylated histone bands were visualized by autoradiography, analyzed using a Phosphoimager (Storm 860, Molecular Dynamics, GE Healthcare, Prague, Czech Republic), and quantified using Image Studio Lite software (LI-COR Biosciences, v. 5.2, Lincoln, NE, USA) as described by Zachleder et al. [4].

\section{Results}

\subsection{Cell Cycle Progression Differs between $30^{\circ} \mathrm{C}$ and $39^{\circ} \mathrm{C}$, but Growth Remains Unaffected}

When a synchronized culture was grown at $30{ }^{\circ} \mathrm{C}$, it sequentially attained three $\mathrm{CPs}$, with midpoints at approximately 3,6 , and $12 \mathrm{~h}$ after the onset of light (Figure 2, blue circles, squares and triangles, respectively). Each of the CPs switched on one reproductive sequence, leading to three rounds of nuclear division (Figure 2, red circles, squares and triangles, respectively) in a clustered pattern with midpoints within a short time interval of three hours between 13 and $16 \mathrm{~h}$. Each of the nuclear divisions was immediately followed by protoplast fission (Figure 2, green circles, squares and triangles respectively), so no multinuclear intermediates occurred in the cells. The divided protoplasts remained attached within the mother cell wall until the freely moving flagellated daughter cells were formed and released with a midpoint at $17 \mathrm{~h}$ (for a schematic illustration, see Figure 1).

Entry into the cell cycle was preceded by growth to a critical cell size. Microscopically, cells grown at $30^{\circ} \mathrm{C}$ started as flagellated daughter cells (Figure 3A) that increased in size (Figure 3B) until they underwent cell division and gave rise to the next generation of daughter cells (Figure $3 \mathrm{C}$ ), which could then undergo a similar sequence, provided that the growth conditions did not change. To study the effect of temperature on the cell cycle, we determined the lowest supraoptimal temperature that caused cell cycle arrest but did not affect growth. The heat stress temperature $\left(42^{\circ} \mathrm{C}\right)$ was not appropriate because this not only caused cell cycle arrest but also affected growth and cellular metabolism [35]. For Chlamydomonas, the optimal growth temperature was $35^{\circ} \mathrm{C}$, and at temperatures above $36{ }^{\circ} \mathrm{C}$, protoplast fission and daughter cell release were inhibited [5]. Temperatures between 36 and $42{ }^{\circ} \mathrm{C}$ were, therefore, tested for their potential to cause cell cycle arrest. The lowest effective temperature was $39^{\circ} \mathrm{C}$, when protoplast division and daughter cell release were inhibited in $95 \%-100 \%$ of the population. In contrast, at $39^{\circ} \mathrm{C}$, comparing cell size and RNA (Figures 3 and 4), cells grew similarly to controls. This was true until cells at $30^{\circ} \mathrm{C}$ started to divide. Thereafter, the cells at $39^{\circ} \mathrm{C}$ continued to grow for at least another $10 \mathrm{~h}$, to more than double the size $(1409.7 \pm 50.7)$ of cells grown at $30^{\circ} \mathrm{C}$ (640.3 \pm 43.7$)$ (Figure 3). These large cells then became pale due to decreased chlorophyll content and ceased growth (Figure 3F,G), but they retained a high content of starch (Figure 3G,H). The cells grown at $39^{\circ} \mathrm{C}$ did not divide for the entire duration of the experiment (Figure 3G), corresponding to a duration of almost two control cell cycles. 

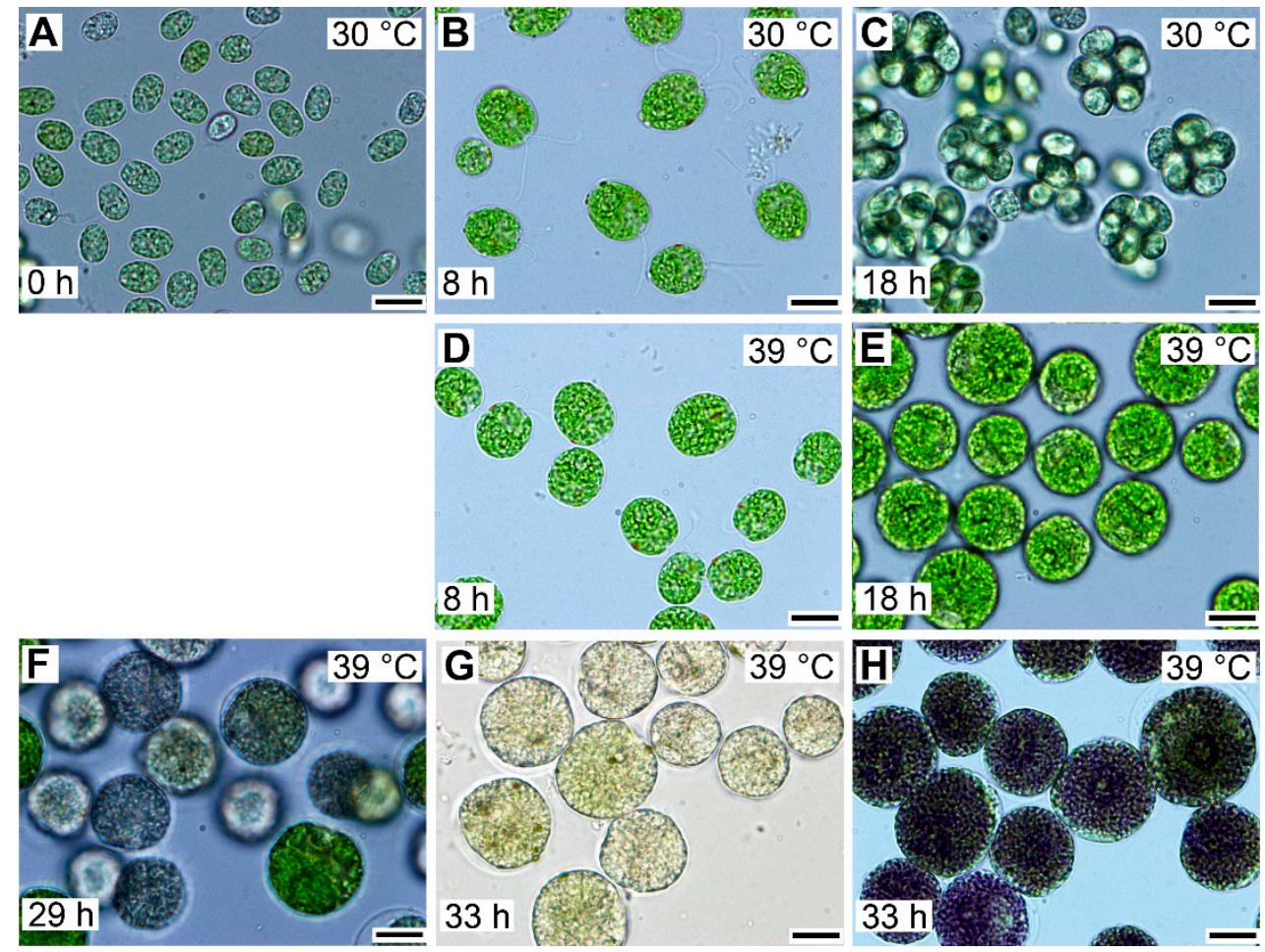

Figure 3. Photomicrographs of cells in synchronized cultures of Chlamydomonas reinhardtii grown in incident light $500 \mu \mathrm{mol} \mathrm{m} \mathrm{m}^{-2} \mathrm{~s}^{-1}$ at $30^{\circ} \mathrm{C}(\mathbf{A}-\mathbf{C})$ or $39^{\circ} \mathrm{C}(\mathbf{D}-\mathbf{H})$. The cultivation temperature and the cell age in hours are indicated in the pictures. The control cells, grown at $30^{\circ} \mathrm{C}$, divided at $18 \mathrm{~h}$ and thereafter entered a new cell cycle sequence similar to the one depicted in panels A-C. In contrast, the cells grown at $39^{\circ} \mathrm{C}$ did not divide even after prolonged cultivation. They attained a maximum size after about $29 \mathrm{~h}$ of growth and started to lose chlorophyll (F). After $33 \mathrm{~h}$, the majority of the cells lost chlorophyll and accumulated enormous amounts of starch in the form of grains (G), which can be visualized by staining with Lugol solution (H). Cultures at both 30 and $39^{\circ} \mathrm{C}$ started from the same initial culture, so the cells depicted in panel A for $30^{\circ} \mathrm{C}$ reflect also the cells present at $0 \mathrm{~h}$ at $39^{\circ} \mathrm{C}$. Bar $=10 \mu \mathrm{m}$.

The total RNA content (Figure 4A) doubled several times in cells grown at $30{ }^{\circ} \mathrm{C}$, reached a maximum just before cellular division, and then decreased once the cells had divided (Figure 4A). DNA replication, as the first reproductive event, started by the 9th to 10th hour of the cell cycle and was completed by the 14th hour. During this time, DNA multiplied about 8-fold, corresponding to the production of 8 daughters per mother cell, and decreased again with cell division (Figure 4B). Cells grown at $39^{\circ} \mathrm{C}$ accumulated RNA with similar kinetics to those of the control culture at $30^{\circ} \mathrm{C}$. They continued to grow and increased total RNA even at the time corresponding to division in the control cells, reaching about a 1.6-fold higher content of RNA compared to the maximum attained at $30^{\circ} \mathrm{C}$ (Figure 4A). No division occurred at $39^{\circ} \mathrm{C}$. DNA replication at $39^{\circ} \mathrm{C}$ started with about a $6 \mathrm{~h}$ delay, but it only increased about 3- to 4-fold compared to initial values and was, thus, more than 2-fold lower than the maximum seen in control cultures grown at $30^{\circ} \mathrm{C}$ (Figure $4 \mathrm{~B}$ ). 

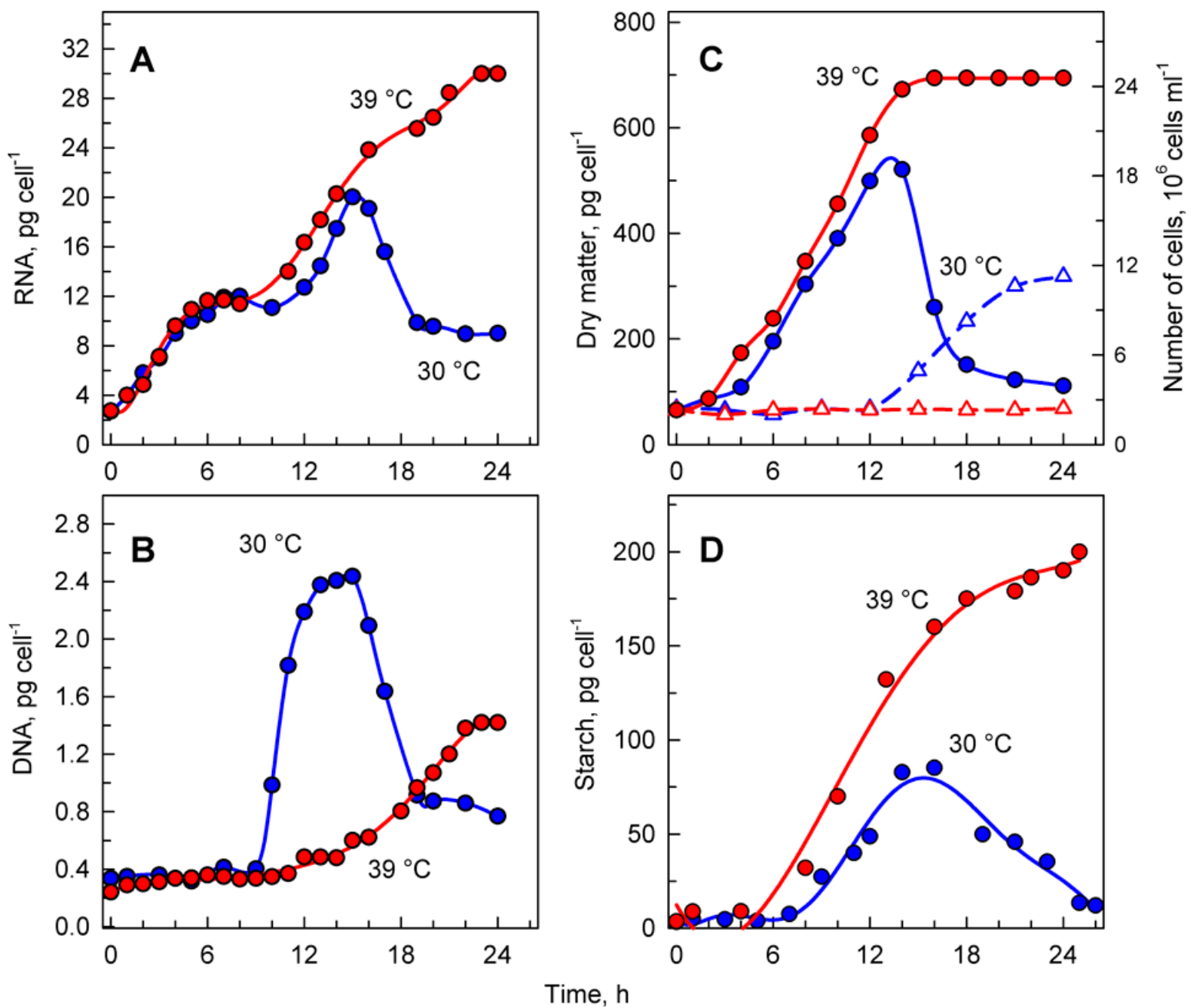

Figure 4. The course of RNA synthesis (A), DNA replications (B), changes in the number of cells and concentration of dry matter (C), and total starch (D) in the synchronized culture of Chlamydomonas reinhardtii grown under continuous illumination of incident light intensity $500 \mu \mathrm{mol} \mathrm{m} \mathrm{m}^{-2} \mathrm{~s}^{-1}$ at $30{ }^{\circ} \mathrm{C}$ (blue lines and symbols) or $39^{\circ} \mathrm{C}$ (red lines and symbols).

\subsection{Starch Reserves Accumulate and are Not Consumed at $39^{\circ} \mathrm{C}$}

Growth at 30 and $39^{\circ} \mathrm{C}$ was comparable with changes in total RNA content (Figure 4A) as well as for increases in dry matter (Figure $4 \mathrm{C}$ ). The two cultures had virtually the same kinetics of dry matter increase up to the time when cellular divisions started in the control cultures (Figure 4C). In the control cultures, cell division led to a drop in dry matter per cell (Figure 4C), whilst the culture at $39^{\circ} \mathrm{C}$ continued to increase dry matter for at least two more hours.

Microscopic analysis indicated that cells grown at $39{ }^{\circ} \mathrm{C}$ accumulated starch (Figure 3G,H). In C. reinhardtii, starch is used as a primary storage molecule and serves as the energy supply for cell reproduction as well as dark metabolism. In the culture grown at $30^{\circ} \mathrm{C}$, starch steadily increased up to about 10-times the initial value. About the time when the cells divided, the starch content plateaued and then decreased, probably because it was used as a source of energy and carbon for cell reproduction (Figure $4 \mathrm{D}$, blue circles). The culture grown at $39^{\circ} \mathrm{C}$ accumulated starch much faster than at $30^{\circ} \mathrm{C}$ (Figure $4 \mathrm{D}$, red circles). The final total starch content per cell at $39^{\circ} \mathrm{C}$ was more than 2 -fold higher than that of the maximum reached at $30{ }^{\circ} \mathrm{C}$ (Figure 4D). The rate of accumulation of starch at $39^{\circ} \mathrm{C}$ (Figure 4D) was much higher than that of other growth processes (total RNA, dry matter) at the same temperature (Figure $4 \mathrm{~A}, \mathrm{C}$ ). 


\subsection{Cells Transferred from $39^{\circ} \mathrm{C}$ to $30^{\circ} \mathrm{C}$ Recover from Cell Cycle Arrest}

The effects of the supraoptimal temperature, $39^{\circ} \mathrm{C}$, seemed to be at least two-fold. Firstly, it induced cell cycle arrest, and secondly, in the absence of cell division, it caused a rapid accumulation of starch at rates exceeding synthesis of other metabolites. However, is the effect reversible? Cultures grown at $39^{\circ} \mathrm{C}$ were transferred to the dark at $30^{\circ} \mathrm{C}$, where growth was inhibited due to the absence of an energy source, but the cell cycle continued. Control cultures grown at $30^{\circ} \mathrm{C}$ attained 3 consecutive $\mathrm{CPs}$, leading to initiation of the reproductive sequence for division into 2,4 , and 8 daughter cells (Figure 5A, blue lines), and thereafter divided into 8 daughter cells with a midpoint at the 17th hour (Figure 2).

Synchronized cells cultivated at $39^{\circ} \mathrm{C}$ grew similarly to their $30^{\circ} \mathrm{C}$ controls (Figures 3 and 4), but nuclear division and protoplast fission were inhibited, and daughter cells were not formed (Figure 3) even when put into darkness at $39^{\circ} \mathrm{C}$. This demonstrated that cell cycle arrest was dependent solely on temperature and not on a combination of light and temperature stress. Because of the absence of cell division in dark at $39{ }^{\circ} \mathrm{C}$, to assess attaining of $\mathrm{CP}$, cells growing at $39^{\circ} \mathrm{C}$ were transferred to darkness at $30^{\circ} \mathrm{C}$ (Figure 5A, red curves). At this temperature, the cells completed nuclear and cellular divisions and produced daughter cells, suggesting that during the relatively undisturbed growth at $39^{\circ} \mathrm{C}, \mathrm{CPs}$ were, indeed, attained, but the corresponding reproductive processes were blocked. The attainment of $\mathrm{CPs}$ at $39^{\circ} \mathrm{C}$ was similar to that at $30^{\circ} \mathrm{C}$, with the first $\mathrm{CP}$ being delayed by about two hours at $39^{\circ} \mathrm{C}$, and the proportion of the population attaining the third $\mathrm{CP}$ for division into eight daughter cells was about $25 \%$ lower than controls (Figure $5 \mathrm{~A}$ ). After 16 or more hours of cultivation at $39^{\circ} \mathrm{C}$, the cells were no longer capable of complete recovery from the effect of high temperature, and the number of committed cells started to decrease (Figure 5A). The relationship between growth and $\mathrm{CP}$ attainment was maintained, as the proportion of dividing daughter cells produced in the dark increased with the prolongation of growth at $39^{\circ} \mathrm{C}$. Consequently, the number of daughter cells formed in the population that was transferred to darkness at $30^{\circ} \mathrm{C}$ increased (Figure $5 \mathrm{~B}-\mathrm{G}$ ) until the inhibitory effect of prolonged cultivation at $39^{\circ} \mathrm{C}$ was manifested from the 16 th hour (Figure $5 \mathrm{H}$ ). Daughter cell release occurred at about the same time in cultures darkened at the 6th, 8th, 10th, and 12th hours (Figure 5C-F). It was slightly delayed in transfers after the 4th and 14th hours (Figure 5B,G) and delayed most in cultures transferred after the 16th hour. The delay in daughter cell release in cultures transferred at the 14th and 16th hour was most probably dictated by the fact that the entire reproductive sequence, including mitosis, protoplast fission, and daughter cell release, could have proceeded only after transfer to $30^{\circ} \mathrm{C}$.

A more detailed analysis of the dark $30^{\circ} \mathrm{C}$ recovery from growth at $39^{\circ} \mathrm{C}$ confirmed that growth ceased once the cells were put into darkness. This is clear from changes in total RNA and protein as well as the amount of dry matter that remained constant after the dark transfer or was slightly reduced, probably due to using some reserves for dark metabolism (Figure $6 \mathrm{~A}-\mathrm{C}$ ). Based on changes in mean cell volume, cells transferred to darkness at $30^{\circ} \mathrm{C}$, after 4 and $8 \mathrm{~h}$ at $39^{\circ} \mathrm{C}$, started to release daughter cells with a slight delay compared to control cells grown at $30^{\circ} \mathrm{C}$ (Figure $6 \mathrm{D}$ ); this was also confirmed by the increase in cell number (Figure 6F). Daughter cell release was delayed by $4-6 \mathrm{~h}$ in cultures transferred at 12 and $14 \mathrm{~h}$ (Figure 6D,F). Cells transferred after $16 \mathrm{~h}$ were not only slightly delayed in daughter cell release, as shown by changes in mean cell volume (Figure 6D), but the number of daughter cells released (2.6-fold increase) was lower than the number expected from direct counting of cell divisions (3.8-fold increase; compare Figures $5 \mathrm{H}$ and $6 \mathrm{~F}$ ). This was caused by some of the divided daughter cells not hatching and staying connected in clumps. 

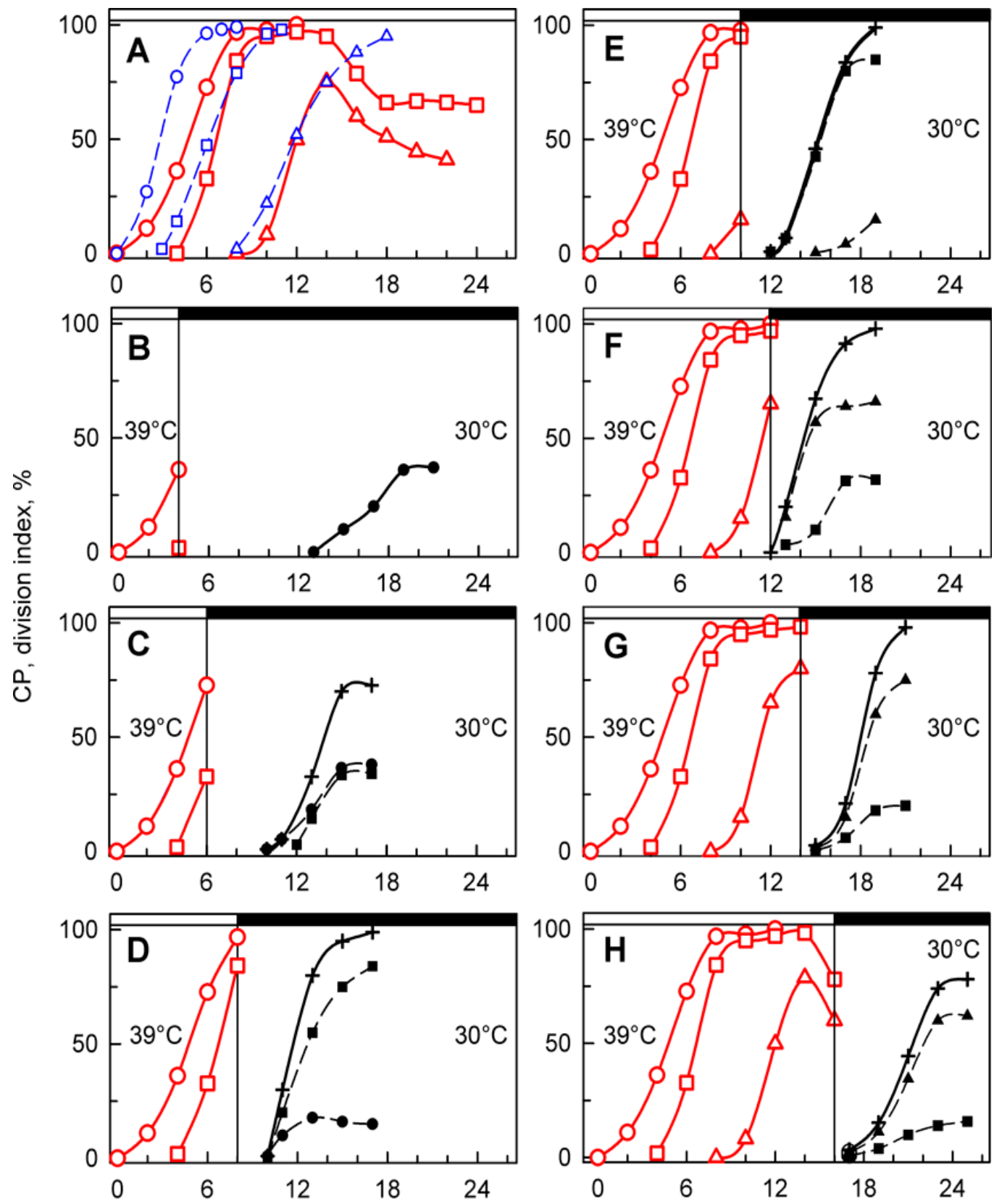

Time, $\mathrm{h}$

Figure 5. Time courses of individual CPs and cellular divisions in synchronized populations of Chlamydomonas reinhardtii. Panel A, the cells were grown in light at $30^{\circ} \mathrm{C}$ (blue lines) or $39^{\circ} \mathrm{C}$ (red lines); panels B-H, the cells were grown at $39^{\circ} \mathrm{C}$ and then placed in the dark after 4, 6, 8, 10, 12, 14, and $16 \mathrm{~h}$, respectively, and kept at $30^{\circ} \mathrm{C}$. No cell divisions occurred at $39{ }^{\circ} \mathrm{C}(\mathrm{A})$. Blue lines (CP indices): cumulative percentage of cells in a given population $(100 \%)$ grown at $30^{\circ} \mathrm{C}$ that attained commitment points (CPs) for the first (circles), second (squares), and third (triangles) reproductive sequences. Red lines (CP indices): the cells were grown at $39^{\circ} \mathrm{C}$ and transferred bihourly to the dark at $30^{\circ} \mathrm{C}$. The cumulative percentage of 2,4 , and 8 daughter cells released in the dark in a given population $(100 \%)$ is plotted as the attainment of the commitment points for the first (circles), second (squares), and third (triangles) reproductive sequences. Black dashed lines (division indices): cumulative percentage of cells that completed the first (full circles), second (full squares), and third (full triangles) cellular divisions and released 2, 4, or 8 daughter cells in a given population (100\%). Black full lines, crosses: cumulative percentage of all cells in a given population $(100 \%)$ that released daughter cells at $30^{\circ} \mathrm{C}$ in dark. Times of transfer into darkness at $30^{\circ} \mathrm{C}$ are indicated by vertical lines and by dark boxes above the graphs. 

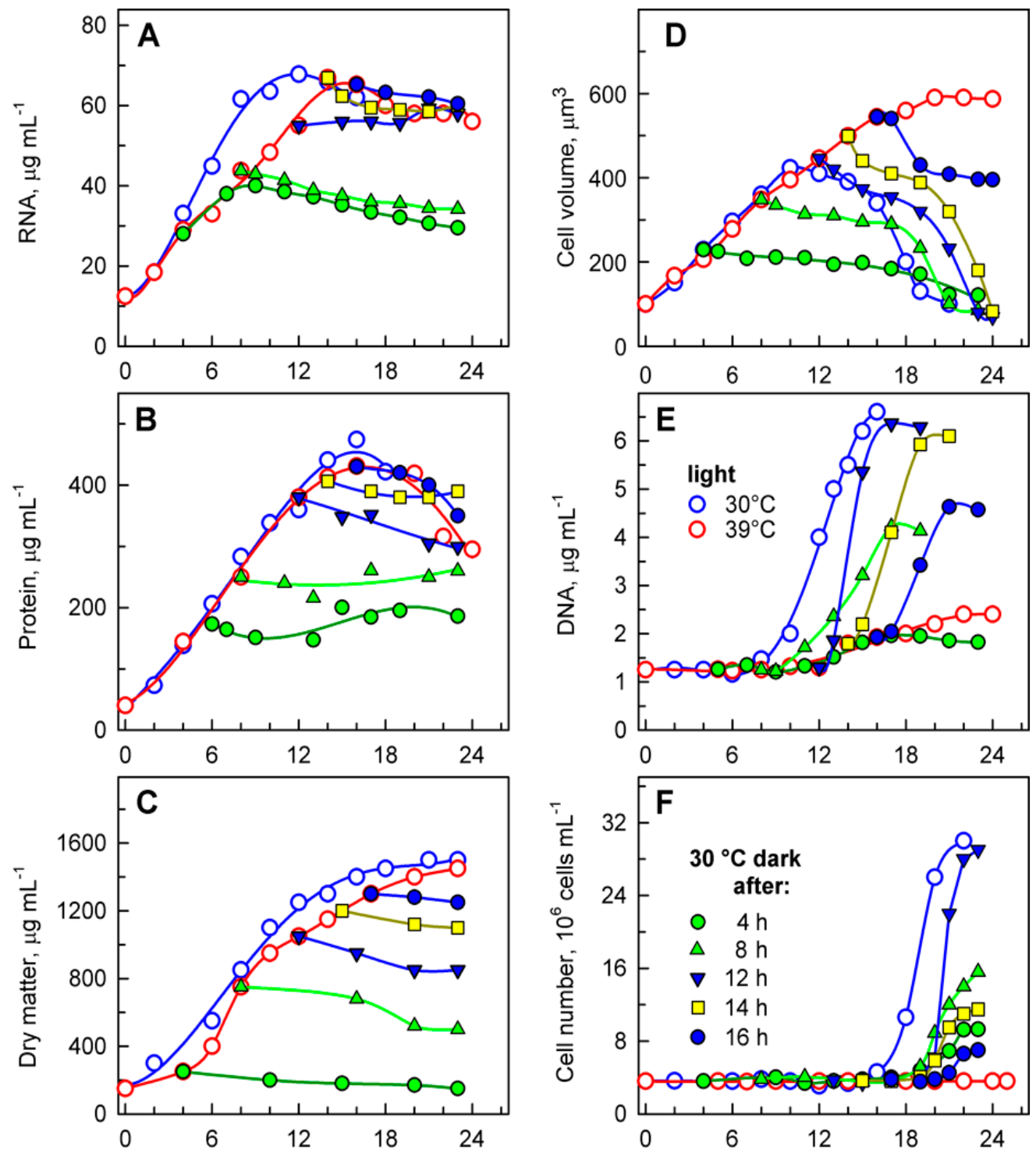

Time, $\mathrm{h}$

Figure 6. Changes in total RNA (A), total protein (B), dry matter (C), mean cell volume (D), DNA (E), and number of cells (F) in synchronized populations of Chlamydomonas reinhardtii grown at $30^{\circ} \mathrm{C}$ (blue open circles), $39^{\circ} \mathrm{C}$ (red open circles), and transferred from $39^{\circ} \mathrm{C}$ into the dark at $30^{\circ} \mathrm{C}$ at the 4 th hour (green solid circles), 8th hour (green solid triangles), 12th hour (blue solid converted triangles), 14th hour (yellow solid squares), and 16th hour (blue solid circles), respectively.

DNA replication increased with the length of incubation in light at $39^{\circ} \mathrm{C}$, from 4 to $14 \mathrm{~h}$ (Figure $6 \mathrm{~F}$ ), but started to decrease from $16 \mathrm{~h}$ (Figure $6 \mathrm{~F}$ ). The timing of DNA replication reflected the timing of cell division (compare Figures 5 and $6 \mathrm{E}$ ), as is typical for $C$. reinhardtii. DNA replication was delayed by about $2 \mathrm{~h}$ in cultures transferred after 8 and $12 \mathrm{~h}$ (Figure 6E). The delay increased to $6 \mathrm{~h}$ for cultures transferred after $14 \mathrm{~h}$, and to $8 \mathrm{~h}$ for cultures transferred after $16 \mathrm{~h}$ (Figure 6E). The delay suggests that DNA replication was inhibited by the supraoptimal temperature treatment and could fully recover only after transfer to $30^{\circ} \mathrm{C}$. The number of daughter cells released also increased with the length of incubation in light at $39^{\circ} \mathrm{C}$, from 4 to $12 \mathrm{~h}$ (Figure $6 \mathrm{~F}$ ), and decreased thereafter (Figure $6 \mathrm{~F}$ ). These data (Figure 6E,F) confirmed results from direct microscopy counts of the number of daughter cells per mother cell (Figure 5) and further strengthened the idea of an inhibitory effect of prolonged incubation at supraoptimal temperatures. The extent of the effect was manifested in descending order, from daughter cell release, number of daughter cells formed per mother cell, and extent of DNA replication, 
so that DNA replication was the last affected, and daughter cell release was the first to be altered by the supraoptimal temperature.

\subsection{CDK Activity Changes Upon a Shift to Darkness at $30^{\circ} \mathrm{C}$}

A supraoptimal temperature was shown to block the cell cycle, particularly nuclear and cellular divisions, while DNA replication proceeded, albeit later and to a lesser extent. Some of the cell cycle regulatory machinery must, therefore, be active to switch on DNA replication. However, it is not clear whether the limiting factor blocking the cell cycle is related to the activity of key cell cycle regulators, cyclin-dependent kinases (CDKs), or whether activity was not affected and the cell cycle was blocked further downstream. In C. reinhardtii there are two cell cycle regulatory CDKs, CDKA and CDKB $[19,20]$. Temperature-sensitive mutants of both were isolated [20], and their cell cycle regulatory functions were analyzed in detail $[21,36]$. Unfortunately, because of the temperature-sensitivity of the mutants, they could not be used in our experiments. Instead, we adopted a more general analysis of CDK activity in two types of protein mixtures containing different proportions of CDK complexes. Firstly, we analyzed CDK activity in whole cell lysates. Such unpurified extracts contained all the CDK complexes present at the same time in the cells; activity was related to attaining $\mathrm{CP}$ as well as to the completion of nuclear and cellular divisions [37]. Specific mitotic CDK complexes were purified through their affinity to bind to CrCKS1 protein. Activity bound to CrCKS1 protein beads corresponded almost exclusively to the completion of nuclear and cellular divisions [19] and encompassed activities of both CDKA and CDKB complexes [20]. Thus, although both types of protein extracts contained CDKA as well as CDKB complexes, the proportions of the two complexes in the mixture, as well as their activities, might differ because of the isolation procedure.

Activities in whole cell lysates were followed in aliquots of synchronized populations grown in light at 30 or $39^{\circ} \mathrm{C}$, and subsequently transferred from $39^{\circ} \mathrm{C}$ to darkness at $30^{\circ} \mathrm{C}$ (Figure 7). At $30^{\circ} \mathrm{C}$, CDK activity peaked at two distinct time points (Figure 7A). A smaller, less pronounced peak correlated with the attainment of CPs (Figure 5A), and the larger, more pronounced peak correlated with the onset of DNA replication and preceded nuclear and cellular divisions (Figure 7A). Similar peaks were also observed at $39^{\circ} \mathrm{C}$. Their occurrence and duration were affected by temperature. The $\mathrm{CP}$-related peak started at the same time as the control, but its duration was prolonged, in agreement with a slower attainment of $\mathrm{CP}$ at $39^{\circ} \mathrm{C}$ (Figure 7B). The second, more pronounced peak was delayed at $39^{\circ} \mathrm{C}$; it preceded the onset of DNA replication and decreased thereafter (Figure 7B). Since no nuclear and cellular divisions occurred at $39^{\circ} \mathrm{C}$, the peak of whole cell lysate CDK activity seemed to be specifically related to DNA replication. Interestingly, the maxima of the two peaks were comparable at both 30 and $39^{\circ} \mathrm{C}$, although the extent of DNA replication differed between the two cultures (Figure 7A,B).

Transfer from light at $39^{\circ} \mathrm{C}$ to darkness at $30^{\circ} \mathrm{C}$ did not affect the timing of the CP-related peak, but in most cases, it resulted in a shift of timing and extent of CDK activity of the second peaks related to DNA replication, and possibly nuclear and cellular division. For transfer after cultivation for $4 \mathrm{~h}$ in light at $39^{\circ} \mathrm{C}$, the second peak occurred at a comparable time point as at $39^{\circ} \mathrm{C}$ and preceded the onset of DNA replication. This was comparable to the peak in $39^{\circ} \mathrm{C}$ grown cells with similar levels of DNA replication (Figure 7C). For cultures transferred to darkness at $30^{\circ} \mathrm{C}$ after $8 \mathrm{~h}$ at $39^{\circ} \mathrm{C}$, the second peak of CDK activity occurred $3 \mathrm{~h}$ earlier (Figure 7D) and again preceded the onset of DNA replication, followed by nuclear and cellular divisions. The peak was more pronounced either because more DNA was replicated or because of the simultaneous occurrence of nuclear and cellular divisions. After transfer at $12 \mathrm{~h}$, the increase in CDK activity started similarly to the $39^{\circ} \mathrm{C}$ control, but reached the peak five hours later, and the $\mathrm{CDK}$ activity was double that of the peak at $39^{\circ} \mathrm{C}$ (Figure 7E). The increase corresponded with the onset of DNA replication as well as nuclear and cellular divisions that occurred between 12 and $18 \mathrm{~h}$. Once cell division was complete, CDK activity decreased. Transfer after $16 \mathrm{~h}$ at $39^{\circ} \mathrm{C}$ occurred after the DNA replication-related peak was attained at $39^{\circ} \mathrm{C}$, and following the transfer, $\mathrm{CDK}$ activity increased again and attained another peak $2-3 \mathrm{~h}$ later. This peak corresponded to the completion of further DNA replication as well as nuclear and cellular divisions. 


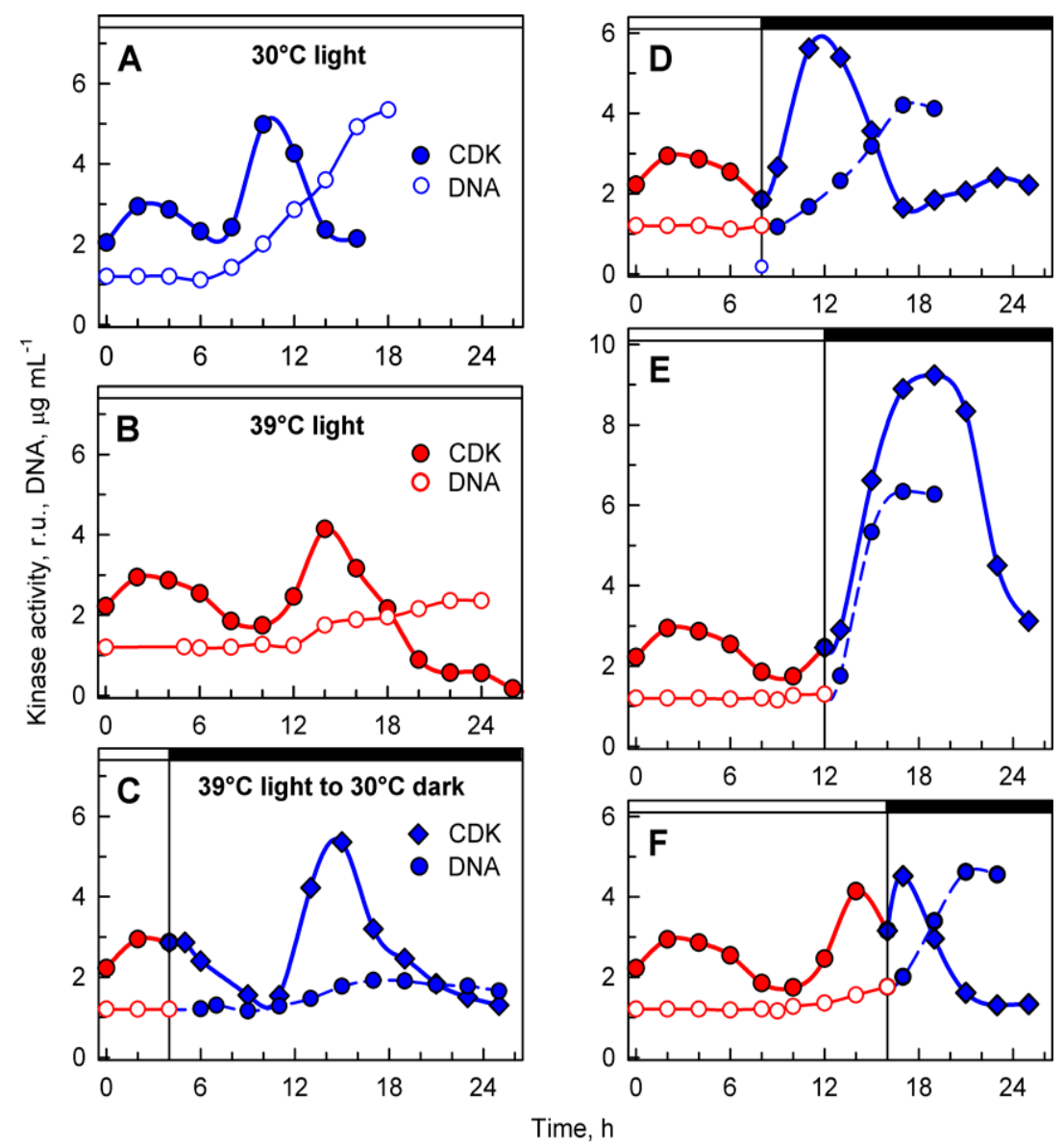

Figure 7. Activity of cyclin-dependent kinase (CDK) in whole-cell lysates prepared from synchronized cultures of Chlamydomonas reinhardtii cultivated under different light and temperature conditions. Panels A, B, the cells were grown in continuous light at $30^{\circ} \mathrm{C}(\mathbf{A})$ or $39{ }^{\circ} \mathrm{C}(\mathbf{B})$; panels $\mathbf{C}-\mathbf{F}$, the cells were grown at $39{ }^{\circ} \mathrm{C}$ and then placed into the dark after $4,8,12$, and $16 \mathrm{~h}$ and kept at $30^{\circ} \mathrm{C}$. Solid blue lines, full circles, kinase activity in cultures grown in continuous light at $30^{\circ} \mathrm{C}$; solid red lines, full circles, kinase activity in cultures grown in continuous light at $39^{\circ} \mathrm{C}$; solid blue lines, diamonds, kinase activity in cultures transferred from light at $39{ }^{\circ} \mathrm{C}$ to darkness at $30{ }^{\circ} \mathrm{C}$. Solid blue lines, empty circles, DNA content in cells grown at $30^{\circ} \mathrm{C}$; solid red lines, empty circles, DNA content in cells grown at $39{ }^{\circ} \mathrm{C}$; dashed blue lines, full circles, DNA content in cells transferred from 39 to $30^{\circ} \mathrm{C}$. Times of transfer into darkness are indicted by vertical lines and by dark boxes above the graphs.

To complement the analyses of whole cell lysate kinase activities, CDK activity bound to CrCKS1 beads was also assessed in the same set of experiments (Figure 8). At $30^{\circ} \mathrm{C}$, the CrCKS1 bead-bound CDK activity increased at the 10th hour and stayed elevated until the 18th hour, when it then decreased (Figure 8A). This peak corresponded with the onset of DNA replication (Figure 4B. blue curve), was maintained over three rounds of DNA replication and nuclear and cell divisions (Figure 2), and fell after they were completed. At $39^{\circ} \mathrm{C}$, the increase in CDK activity started about two hours earlier, reached similar levels as at $30^{\circ} \mathrm{C}$, and never decreased (Figure 8B), possibly because of the absence of nuclear and cellular divisions. In the culture transferred from $39^{\circ} \mathrm{C}$ to darkness at $30^{\circ} \mathrm{C}$ after $4 \mathrm{~h}$ in light, the increase in kinase activity occurred earlier compared to its mother culture at $39^{\circ} \mathrm{C}$, but the final activities were comparable. The increase in CDK activity preceded, by about $5 \mathrm{~h}$, the onset of cell division in a small proportion of culture, and the activity started to decrease slightly once cell division was complete (Figure $8 \mathrm{C}$ ). For cultures transferred to darkness at $30^{\circ} \mathrm{C}$ after 8 or $10 \mathrm{~h}$ at $39^{\circ} \mathrm{C}$, $\mathrm{CDK}$ activity exceeded that of the original culture at $39^{\circ} \mathrm{C}$ within $3 \mathrm{~h}$ of transfer, reached a peak at the completion of cell division, and decreased thereafter (Figure $8 \mathrm{D}, \mathrm{E}$ ). The culture grown at $30^{\circ} \mathrm{C}$ for 14 or more hours completed cell divisions and released daughter cells (Figures 2, 5A and 8A). Nuclear and 
cell divisions were blocked at $39^{\circ} \mathrm{C}$, but when cultures grown at $39^{\circ} \mathrm{C}$ were transferred into darkness at $30^{\circ} \mathrm{C}$, divisions occurred almost immediately. Within one hour of transfer, fifty percent or more of cells completed the first nuclear and cellular divisions (Figure 8F,G). Nuclear and cellular divisions were accompanied by decreased kinase activities (Figure 8F,G).
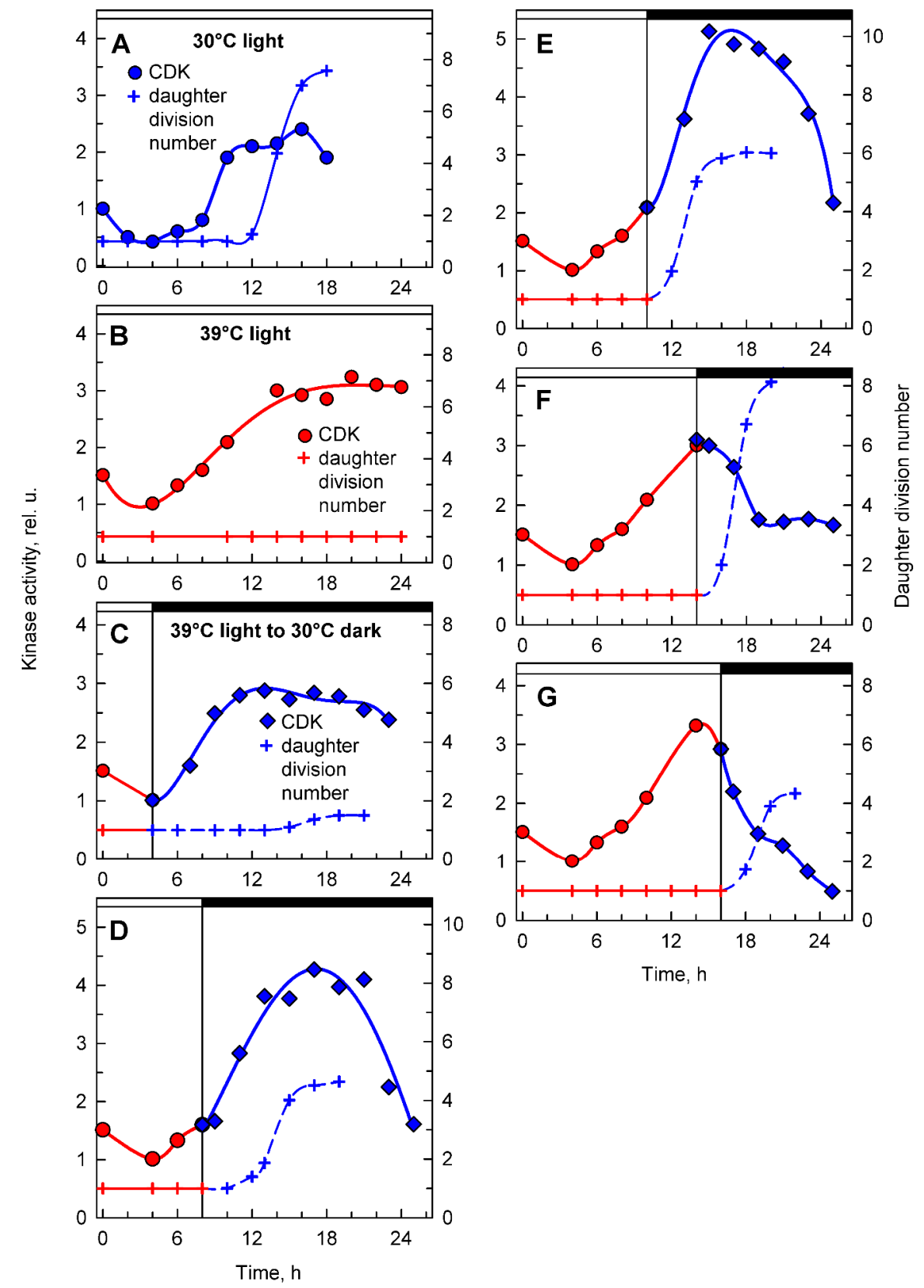

Figure 8. Activity of CDK in CrCKS1-bound fractions prepared from synchronized cultures of Chlamydomonas reinhardtii cultivated under different conditions of light and temperature. Panels A, B, the cells were grown in continuous light at $30^{\circ} \mathrm{C}(\mathbf{A})$ or $39^{\circ} \mathrm{C}(\mathbf{B})$; panels $\mathbf{C}-\mathbf{G}$, the cells were grown at $39^{\circ} \mathrm{C}$ and then placed into darkness after $4,8,10,14$, and $16 \mathrm{~h}$ and kept at $30^{\circ} \mathrm{C}$. Blue lines, circles, kinase activity in cultures grown in continuous light at $30^{\circ} \mathrm{C}$; red lines, circles, kinase activity in cultures grown in continuous light at $39^{\circ} \mathrm{C}$; blue lines, diamonds, kinase activity in cultures transferred from light at $39^{\circ} \mathrm{C}$ into darkness at $30^{\circ} \mathrm{C}$. Blue solid line, crosses, daughter division number-number of daughter cells released per mother cell at $30^{\circ} \mathrm{C}$; red solid line, crosses, daughter division number at $39^{\circ} \mathrm{C}$; blue dashed line, crosses, daughter division number after transfer from $39^{\circ} \mathrm{C}$ to $30^{\circ} \mathrm{C}$. Times of transfer into dark are indicated by vertical lines and by dark boxes above the graphs. 


\section{Discussion}

Cultivation temperature affects the entire metabolism of cells, including their ability to complete the cell cycle. The sensitivities of different metabolic processes are not the same, as shown by the temperature optima for growth and photosynthesis, which can differ by as much as $10^{\circ} \mathrm{C}$ [38]. Similarly, the upper temperature limits for growth, photosynthesis, and respiration can differ [38]. The ability of cells to divide seems to be the most temperature-sensitive process, as cell division is blocked even when growth is barely affected. Indeed, cell division of $C$. reinhardtii was blocked by cultivation at $39^{\circ} \mathrm{C}$, but growth was comparable between 30 and $39^{\circ} \mathrm{C}$ (Figures 3-6). Cells cultivated at $39^{\circ} \mathrm{C}$ exhibited two main effects: (1) cell cycle arrest (Figures 3, 5 and 6) and (2) accumulation of starch (Figure 4); these are probably interconnected. Within the physiological range, a temperature increase of $10^{\circ} \mathrm{C}$ generally leads to a speeding up of metabolism by about two-fold. This is also true for the duration of the cell cycle in C. reinhardtii [2] or in C. eugametos [3]. The fact that growth was not enhanced in the present experiments, as would have been expected within the physiological temperature range, suggested that the higher temperature had some inhibitory effects that lessened the growth rate, which was only slightly higher than at $30^{\circ} \mathrm{C}$ (i.e., to about half of the predicted one). A similar decrease in growth rate, accompanied by successive prolongation of the cell cycle, as well as its individual steps, was shown in cultures of C. reinhardtii [2] and C. eugametos [3] cultivated at temperatures above the optimum. It is, thus, to be expected that a further increase in temperature up to $39^{\circ} \mathrm{C}$, as used in recent experiments, would cause a complete arrest of nuclear and cellular division. It has been established that yet another increase in temperature to a heat shock temperature of $42^{\circ} \mathrm{C}$ has numerous effects on C. reinhardtii; it not only arrested the cell cycle but also caused significant inhibition of growth processes. There was only about a 1.6-fold increase in total protein within $24 \mathrm{~h}$ of heat shock treatment at $42{ }^{\circ} \mathrm{C}$ [35], compared to about a 10 -fold increase in total protein within the same period at $39{ }^{\circ} \mathrm{C}$ (Figure $6 \mathrm{~B}$ ). In contrast, $39^{\circ} \mathrm{C}$ treatment had only a limited specific effect; it negatively affected the cell cycle and positively affected starch accumulation. Cell growth at $39^{\circ} \mathrm{C}$ was not affected for about $18 \mathrm{~h}$ and continued during the period of DNA replication and nuclear and cellular divisions in cultures grown at $30^{\circ} \mathrm{C}$. This led to the accumulation of giant nondividing cells rich in starch. Among the growth parameters, starch was outstanding as the only one showing a striking difference between cultures grown at 30 and $39^{\circ} \mathrm{C}$ (Figure 4). In the control cultures, cells increased their starch content more than 10-fold (up to $80 \mathrm{pg}$ cell $^{-1}$, Figure 4), but a majority of this was used during cell division, even though the cells were grown in continuous light (Figure 4). This confirms that cell reproduction is an extreme energy-demanding process, in which large amounts of energy are required for DNA replication and nuclear and cellular divisions, as was previously shown $[17,39]$. Correspondingly, the blockage of cell division at $39^{\circ} \mathrm{C}$ and prevention of starch expenditure led to the accumulation of high levels of starch. At $39^{\circ} \mathrm{C}$, this was further accentuated by faster starch production at high temperatures and high light (Figure 4). Over-accumulation of starch by a block in cell division has been a recurring theme, as it has been shown for Chlorella vulgaris starved of nitrogen, sulfur, and phosphate [25]; nitrogen- or phosphorus-starved Desmodesmus quadricauda [40,41]; as well as in nitrogen- and sulfur-starved C. reinhardtii [42,43]. Starch accumulation was also induced when nuclear DNA replication was inhibited [44] as well as by high temperature [45]. In contrast, the heat shock treatment of $C$. reinhardtii led to only a $46 \%$ increase in starch content over the $24 \mathrm{~h}$ period, and energy reserves were mostly accumulated in the form of lipids [35]. In algae capable of producing both starch and lipids, starch overproduction is the first response to stress, and with prolongation, it is replaced with lipid production [46,47] possibly to store more energy in a more compact form for stress recovery [48].

The cell cycle arrest at $39^{\circ} \mathrm{C}$ was maintained even in darkness but was removed once the cells were shifted to $30^{\circ} \mathrm{C}$ (Figure 5). With prolonged incubation at $39^{\circ} \mathrm{C}$, the ability of cells to fully recover from the block was decreased. The first affected process was daughter cell splitting; the second, the extent of cell division and the number of daughter cells formed; and the third, the extent of DNA replication (Figures 5 and 6). A similar order of sensitivity, with cell division being the most sensitive process, was also shown for cell cycle arrest following exposure to different concentrations of cadmium 
in Desmodesmus quadricauda, a green alga that does not split daughter cells [49]. Likewise, the formation of palmelloids (i.e., unsplit daughter cells) was characteristic for the salt stress response [50]. Thus, the response to high temperature seems to follow general rules or mechanisms involved in stress responses. The incomplete recovery from cultivation at $39^{\circ} \mathrm{C}$ is in conflict with the presumably complete recovery from heat shock at $42{ }^{\circ} \mathrm{C}[35,51]$. This might seem surprising because the heat shock conditions of $42{ }^{\circ} \mathrm{C}$ were more severe than cultivation at $39^{\circ} \mathrm{C}$. However, the heat shock experiments were carried out with asynchronous cultures, where only about $20 \%$ of the cells in the population were dividing at $25^{\circ} \mathrm{C}$, which is the cultivation temperature used in the experiments [35]. Subtle changes seen in the synchronized cultures grown at $39^{\circ} \mathrm{C}$ would therefore be impossible to detect.

The cell cycle arrest at $39^{\circ} \mathrm{C}$ was the most striking effect of supraoptimal temperature. Its occurrence under heat shock conditions of $42{ }^{\circ} \mathrm{C}$ was hypothesized to be caused by reduced CDK activity [35], but it has never been tested; thus, the mechanism has remained enigmatic. In principle, there are two possible mechanisms: (1) cell cycle arrest due to low CDK activity and/or (2) a cell cycle block downstream of CDK activity. Of all the reproductive processes, DNA replication was the least sensitive to high-temperature treatment (Figures 4 and 6). Similarly, DNA replication was not affected by high-temperature treatment of Chlorella vulgaris, and, instead, the block was just prior to nuclear division [6]. In fact, in Chlorella vulgaris, several rounds of DNA replication were performed, as the final DNA content was 16-fold higher than initial values [6]. In C. reinhardtii, DNA replication increased between two- and four-fold (Figures 4 and 6), so DNA replication was not only delayed in timing but occurred to a lesser extent even at a supraoptimal temperature. Kinase activity in whole-cell extracts preceded DNA replication, decreased once DNA replication ceased, and, thus, apart from timing, did not differ between 30 and $39^{\circ} \mathrm{C}$ (Figure 7). In a simplified system of fission yeast, it was shown that low levels of CDK activity allows DNA replication to occur, whilst higher levels are required for nuclear division [52]. This would fit the hypothesis of reduced CDK activity, allowing DNA replication to occur but being unable to switch on nuclear division. Notwithstanding the fact that the C. reinhardtii cell cycle is regulated by a more complex network of two CDKs, this hypothesis does not fit the data on mitotic kinase activities (Figure 8). Instead, mitotic kinase activities were comparable between 30 and $39^{\circ} \mathrm{C}$. The main difference between the two treatments was stabilization of a high mitotic CDK activity that only decreased after nuclear and cellular divisions (Figure 8). This supports the idea that the cell cycle block occurred downstream of CDK. The mitotic CDK behavior seems to phenocopy that of CDKA kinase in the anaphase-promoting complex (APC) mutant, $c d c 27-6$, with persistent slightly higher kinase activity compared with control cells [21]. This implies involvement of APC in the supraoptimal temperature-induced cell cycle arrest. APC, the main E3 ubiquitin ligase to control mitotic progression and exit in all eukaryotes [53], has been shown to inhibit both CDKA and CDKB in C. reinhardtii [21]. In opisthokonts, APC is activated by mitotic kinases but kept inactive by spindle assembly checkpoint until all chromosomes are properly assembled [54]. Tubulin polymerization is known to be temperature sensitive [55]. Thus, it could be assumed that microtubule and, hence, spindle stability would be affected by supraoptimal temperature, leading to activation of the spindle assembly checkpoint, inhibition of APC, and maintenance of mitotic kinase activity. In the present experiments, the completion of cell division lagged behind the increase in mitotic kinase activity. The delay was successively shortened with the time the culture spent at $39^{\circ} \mathrm{C}$ (Figure 8, compare A and D to E, F, G). This suggests that many of the processes required for completion of mitotic and cellular division may run even at $39^{\circ} \mathrm{C}$, and the cell cycle arrest is located very shortly before the onset of CDK inactivation. This further supports the idea of microtubule stability and possibility of the spindle checkpoint being involved in the arrest.

Author Contributions: Conceptualization, K.B. and V.Z.; methodology, I.I.; validation, K.B., M.V., and V.Z.; formal analysis, I.I.; investigation., I.I., M.V., V.Z., and K.B.; resources, K.B.; data curation, I.I., V.Z., and K.B.; writing—original draft preparation, V.Z., K.B., and I.I.; writing一review and editing, I.I., M.V., V.Z., and K.B.; visualization, V.Z., M.V., and K.B.; supervision, K.B.; project administration, K.B.; funding acquisition, K.B. 
Funding: This research was funded by Grantová Agentura České Republiky, grant number 15-09231S, and by the National Programme of Sustainability I, project no. LO1416.

Acknowledgments: We are obliged to K. Ondrejmišková and J. Sýkorová for excellent technical support. We thank J. D. Brooker for critical reading and language editing of the text.

Conflicts of Interest: The authors declare no conflicts of interest. The funders had no role in the design of the study; in the collection, analyses, or interpretation of data; in the writing of the manuscript, or in the decision to publish the results.

\section{References}

1. Morimura, Y. Synchronous culture of Chlorella. I. Kinetic analysis of the life cycle of Chlorella ellipsoidea as affected by changes of temperature and light intensity. Plant Cell Physiol. 1959, 1, 49-62.

2. Vítová, M.; Bišová, K.; Hlavová, M.; Kawano, S.; Zachleder, V.; Čížková, M. Chlamydomonas reinhardtii: Duration of its cell cycle and phases at growth rates affected by temperature. Planta 2011, 234, 599-608. [CrossRef] [PubMed]

3. Zachleder, V.; van den Ende, H. Cell cycle events in the green alga Chlamydomonas eugametos and their control by environmental factors. J. Cell Sci. 1992, 102, 469-474.

4. Zachleder, V.; Ivanov, I.; Vítová, M.; Bišová, K. Effects of cyclin-dependent kinase activity on the coordination of growth and the cell cycle in green algae at different temperatures. J. Exp. Bot. 2019, 70, 845-858. [CrossRef] [PubMed]

5. Lien, T.; Knutsen, G. Synchronous growth of Chlamydomonas reinhardtii (Chlorophyceae): A review of optimal conditions. J. Phycol. 1979, 15, 191-200. [CrossRef]

6. Šetlík, I.; Zachleder, V.; Doucha, J.; Berková, E.; Bartoš, J. The nature of temperature block in the sequence of reproductive processes in Chlorella vulgaris BEIJERINCK. Arch. Hydrobiol. Suppl. 49 Algol. Stud. 1975, 14, 70-104.

7. Coleman, A.W. The nuclear-cell cycle in Chlamydomonas (Chlorophyceae). J. Phycol. 1982, 18, $192-195$. [CrossRef]

8. Craigie, R.A.; Cavalier-Smith, T. Cell volume and the control of the Chlamydomonas cell cycle. J. Cell Sci. 1982, 54, 173-191.

9. Lien, T.; Knutsen, G. Synchronized cultures of a cell wall-less mutant of Chlamydomonas reinhardii. Arch. Microbiol. 1976, 108, 189-194. [CrossRef]

10. Donnan, L.; John, P.C.L. CeII cycle control by timer and sizer in Chlamydomonas. Nature 1983, 304, 630-633. [CrossRef]

11. John, P.C.L. Control of the cell division cycle in Chlamydomonas. Microbiol. Sci. 1984, 1, 96-101. [PubMed]

12. John, P.C.L. Control points in the Chlamydomonas cell cycle. In Algal Development; Wiesnar, W., Robinson, D.G., Starr, R.C., Eds.; Springer: Berlin, Germany, 1987; pp. 9-16.

13. Zachleder, V.; Schläfli, O.; Boschetti, A. Growth-controlled oscillation in activity of histone H1 kinase during the cell cycle of Chlamydomonas reinhardtii (Chlorophyta). J. Phycol. 1997, 33, 673-681. [CrossRef]

14. Bišová, K.; Zachleder, V. Cell-cycle regulation in green algae dividing by multiple fission. J. Exp. Bot. 2014, 65, 2585-2602. [CrossRef] [PubMed]

15. Zachleder, V.; Bišová, K.; Vítová, M. The cell cycle of microalgae. In The Physiology of Microalgae; Borowitzka, M.A., Beardall, J., Raven, J.A., Eds.; Springer: Dordrecht, The Netherlands, 2016; Volume 6, pp. 3-46.

16. Donnan, L.; John, P.C.L. Timer and sizer controls in the cell cycles of Chlamydomonas and Chlorella. In The Microbial Cell Cycle; Nurse, P., Streiblová, E., Eds.; CRC Press: Boca Raton, FL, USA, 1984; pp. 231-251.

17. Vítová, M.; Bišová, K.; Umysová, D.; Hlavová, M.; Kawano, S.; Zachleder, V.; Čížková, M. Chlamydomonas reinhardtii: Duration of its cell cycle and phases at growth rates affected by light intensity. Planta 2011, 233, 75-86. [CrossRef] [PubMed]

18. John, P.C.; Sek, F.J.; Lee, M.G. A homolog of the cell cycle control protein p34 ${ }^{\text {cdc2 }}$ participates in the division cycle of Chlamydomonas, and a similar protein is detectable in higher plants and remote taxa. Plant Cell 1989, 1, 1185-1193.

19. Bisova, K.; Krylov, D.M.; Umen, J.G. Genome-wide annotation and expression profiling of cell cycle regulatory genes in Chlamydomonas reinhardtii. Plant Physiol. 2005, 137, 1-17. [CrossRef] 
20. Tulin, F.; Cross, F.R. A microbial avenue to cell cycle control in the plant superkingdom. Plant Cell 2014, 26, 4019-4038. [CrossRef]

21. Atkins, K.C.; Cross, F. Inter-regulation of CDKA/CDK1 and the plant-specific cyclin-dependent kinase CDKB in control of the Chlamydomonas cell cycle. Plant Cell 2018, 30, 429-446. [CrossRef]

22. Sueoka, N. Mitotic replication of deoxyribonucleic acid in Chlamydomonas reinhardtii. Proc. Natl. Acad. Sci. USA 1960, 46, 83-91. [CrossRef]

23. Zachleder, V.; Šetlík, I. Effect of irradiance on the course of RNA synthesis in the cell cycle of Scenedesmus quadricauda. Biol. Plant. 1982, 24, 341-353. [CrossRef]

24. Hlavová, M.; Vítová, M.; Bišová, K. Synchronization of green algae by light and dark regimes for cell cycle and cell division studies. In Plant Cell Division; Caillaud, M.-C., Ed.; Springer Science: New York, NY, USA, 2016; pp. 3-16.

25. Brányiková, I.; Maršálková, B.; Doucha, J.; Brányik, T.; Bišová, K.; Zachleder, V.; Vítová, M. Microalgae-novel highly efficient starch producers. Biotechnol. Bioeng. 2011, 108, 766-776. [CrossRef] [PubMed]

26. Wanka, F. Über den Einfluss des Lichts auf die Nucleinsäuresynthese bei Synchronkulturen von Chlorella pyrenoidosa. Ber. Dtsch. Bot. Ges. 1962, 75, 457-464.

27. Lukavský, J.; Tetík, K.; Vendlová, J. Extraction of nucleic acid from the alga Scenedesmus quadricauda. Arch. Hydrobiol. Suppl. 41 Algol. Stud. 1973, 9, 416-426.

28. Decallonne, J.R.; Weyns, C.J. A shortened procedure of the diphenylamine reaction for measurement of deoxyribonucleic acid by using light activation. Anal. Biochem. 1976, 74, 448-456. [CrossRef]

29. Zachleder, V. Optimization of nucleic acids assay in green and blue-green algae: Extraction procedures and the light-activated reaction for DNA. Arch. Hydrobiol. Suppl. 67 Algol. Stud. 1984, 36, 313-328. [CrossRef]

30. Lowry, O.H.; Rosenbrough, N.S.; Farr, A.L.; Randall, R.J. Protein measurement with the folin-phenol reagent. J. Biol. Chem. 1951, 193, 265-275.

31. McCready, R.M.; Guggolz, J.; Silviera, V.; Owens, H.S. Determination of starch and amylose in vegetables. Anal. Chem. 1950, 22, 1156-1158. [CrossRef]

32. Hlavová, M.; Čížková, M.; Vítová, M.; Bišová, K.; Zachleder, V. DNA damage during G2 phase does not affect cell cycle progression of the green alga Scenedesmus quadricauda. PLoS ONE 2011, 6, e19626. [CrossRef]

33. Langan, T.A.; Gautier, J.; Lohka, M.; Hollingsworth, R.; Moreno, S.; Nurse, P.; Maller, J.; Sclafani, R.A. Mammalian growth-associated H1 histone kinase: A homologue of cdc2+/CDC28 protein kinases controlling mitotic entry in yeast and frog cells. Mol. Cell. Biol. 1989, 9, 3860-3868. [CrossRef]

34. Laemmli, U.K. Cleavage of structural proteins during the assembly of the head of bacteriophage T4. Nature 1970, 227, 680-685. [CrossRef]

35. Hemme, D.; Veyel, D.; Muhlhaus, T.; Sommer, F.; Juppner, J.; Unger, A.K.; Sandmann, M.; Fehrle, I.; Schonfelder, S.; Steup, M.; et al. Systems-wide analysis of acclimation responses to long-term heat stress and recovery in the photosynthetic model organism Chlamydomonas reinhardtii. Plant Cell 2014, 26, 4270-4297. [CrossRef]

36. Tulin, F.; Cross, F.R. Cyclin-dependent kinase regulation of diurnal transcription in Chlamydomonas. Plant Cell 2015, 27, 2727-2742. [CrossRef] [PubMed]

37. Zachleder, V. The course of reproductive events in the chloroplast cycle of the chlorococcal alga Scenedesmus quadricauda as revealed by using inhibitors of DNA replication. Plant Cell Physiol. 1997, 38, 56.

38. Sorokin, C. Tabular comparative data for the low-and high-temperature strains of Chlorella. Nature 1959, 184, 613-614. [CrossRef] [PubMed]

39. Wanka, F. Ultrastructural changes during normal and colchicine-inhibited cell division of Chlorella. Protoplasma 1968, 66, 105-130. [CrossRef] [PubMed]

40. Ballin, G.; Doucha, J.; Zachleder, V.; Šetlík, I. Macromolecular syntheses and the course of cell cycle events in the chlorococcal alga Scenedesmus quadricauda under nutrient starvation: Effect of nitrogen starvation. Biol. Plant. 1988, 30, 81-91. [CrossRef]

41. Zachleder, V.; Ballin, G.; Doucha, J.; Šetlík, I. Macromolecular syntheses and the course of cell cycle events in the chlorococcal alga Scenedesmus quadricauda under nutrient starvation: Effect of phosphorus starvation. Biol. Plant. 1988, 30, 92-99. [CrossRef] 
42. Siaut, M.; Cuine, S.; Cagnon, C.; Fessler, B.; Nguyen, M.; Carrier, P.; Beyly, A.; Beisson, F.; Triantaphylides, C.; Li-Beisson, Y.; et al. Oil accumulation in the model green alga Chlamydomonas reinhardtii: Characterization, variability between common laboratory strains and relationship with starch reserves. BMC Biotechnol. 2011, 11, 7. [CrossRef]

43. Philipps, G.; Happe, T.; Hemschemeier, A. Nitrogen deprivation results in photosynthetic hydrogen production in Chlamydomonas reinhardtii. Planta 2012, 235, 729-745. [CrossRef]

44. Zachleder, V. The effect of hydroxyurea and fluorodeoxyuridine on cell cycle events in the chlorococcal alga Scenedesmus quadricauda (Chlorophyta). J. Phycol. 1994, 30, 274-279. [CrossRef]

45. Semenenko, V.E.; Vladimirova, M.G.; Orleanskaya, O.B. Physiological characteristics of Chlorella sp. K under conditions of high extremal temperatures I. Uncoupling effect of extreme temperatures on the cellular functions of Chlorella. Plant Physiol. 1967, 14, 612-625.

46. Fernandes, B.; Teixeira, J.; Dragone, G.; Vicente, A.A.; Kawano, S.; Bišová, K.; Přibyl, P.; Zachleder, V.; Vítová, M. Relationship between starch and lipid accumulation induced by nutrient depletion and replenishment in the microalga Parachlorella kessleri. Bioresour. Technol. 2013, 144, 268-274. [CrossRef] [PubMed]

47. Mizuno, Y.; Sato, A.; Watanabe, K.; Hirata, A.; Takeshita, T.; Ota, S.; Sato, N.; Zachleder, V.; Tsuzuki, M.; Kawano, S. Sequential accumulation of starch and lipid induced by sulfur deficiency in Chlorella and Parachlorella species. Bioresour. Technol. 2013, 129, 150-155. [CrossRef] [PubMed]

48. Roessler, P.G. Environmental control of glycerolipid metabolism in microalgae: Commercial implications and future research directions. J. Phycol. 1990, 26, 393-399. [CrossRef]

49. Bišová, K.; Hendrychová, J.; Cepák, V.; Zachleder, V. Cell growth and division processes are differentially sensitive to cadmium in Scenedesmus quadricauda. Folia Microbiol. 2003, 48, 805-816. [CrossRef]

50. Khona, D.K.; Shirolikar, S.; Gawde, K.K.; Hom, E.; Deodhar, M.A.; D'Souza, J.S. Characterization of salt stress-induced palmelloids in the green alga, Chlamydomonas reinhardtii. Algal Res. 2016, 16, 434-448. [CrossRef]

51. Mühlhaus, T.; Weiss, J.; Hemme, D.; Sommer, F.; Schroda, M. Quantitative shotgun proteomics using a uniform $15 \mathrm{~N}$-labelled standard to monitor proteome dynamics in time course experiments reveals new insights into the heat stress response of Chlamydomonas reinhardtii. Mol. Cell. Biol. 2011, 10.

52. Coudreuse, D.; Nurse, P. Driving the cell cycle with a minimal CDK control network. Nature 2010, 468, 1074-1079. [CrossRef]

53. Marrocco, K.; Bergdoll, M.; Achard, P.; Criqui, M.C.; Genschik, P. Selective proteolysis sets the tempo of the cell cycle. Curr. Opin. Plant Biol. 2010, 13, 631-639. [CrossRef]

54. Castro, A.; Bernis, C.; Vigneron, S.; Labbé, J.-C.; Lorca, T. The anaphase-promoting complex: A key factor in the regulation of cell cycle. Oncogene 2005, 24, 314-325. [CrossRef]

55. Lodish, H.; Berk, A.; Zipursky, S.L.; Matsudaira, P.; Baltimore, D.; Darnell, J. Mol. Cell. Biol.; W. H. Freeman \& Co.: New York, NY, USA, 2000.

(C) 2019 by the authors. Licensee MDPI, Basel, Switzerland. This article is an open access article distributed under the terms and conditions of the Creative Commons Attribution (CC BY) license (http://creativecommons.org/licenses/by/4.0/). 